\title{
Impact of Covid-19 on the built environment
}

\author{
M. Mahima, R. Shanthi Priya, Prashanthini Rajagopal and C. Pradeepa \\ School of Architecture and Interior Design, SRM Institute of Science and Technology, \\ Chengalpattu, India
}

\begin{abstract}
Purpose - This literature review paper aims to discuss the impacts and measures taken on Covid-19 with respect to architecture, built form and its allied fields along with observations from around the world with the end results of its implementation.

Design/methodology/approach - Various research journals from Science Direct and Taylor and Francis among others were referred and reviewed to learn more on Covid-19 along with its impacts on people and their built environment. Keywords that aligned with the topic of interest like pandemic, Covid-19, coronavirus, urban spaces, built environment and built-up space were identified. Research papers that aligned with the scope of the paper and its keywords were found. An excel sheet with the basic data of these papers was written down. The essence of each of these articles were understood and linked with the topic in hand. A review of all these papers was written coherently to the topic. Future scope in this field of study was also identified.

Findings - It discusses the various measures taken around the world in built-up spaces along with the various measures given by researchers, architects and urban planners to mitigate and reduce the transmission of Covid-19 in the built environment and urban spaces. The discussed measures along with observations from around the world have also been discussed with its end results. Discussions and conclusions on these design strategies and recommendations are made with the anticipation of a paradigm shift due to post-pandemic changes. Current scenarios of public spaces in densely populated countries are discussed. Future scope in this ongoing field of study includes measures that can be taken in specific to some particular built-up typologies like markets, theaters, parks, bazaars, etc.

Research limitations/implications - The limitation of this study is the restricting of the study of Covid-19 to only architectural, urban and public realm scales. The study does not facilitate the involvement of other fields and their influence with Covid-19.

Originality/value - This paper has been completely written by the author and the co-authors and has not been copied from any other sources.
\end{abstract}

Keywords Built environment, Built-up space, Coronavirus, Covid-19, Pandemic, Urban spaces

Paper type Literature review

\section{Introduction}

Living in a world with news about Covid-19 spreading everywhere, understanding the impact of the virus on the built environment was the need of the hour. Covid-19 as explained by the World Health Organization in their article "COVID-19 strategy update", posted on 14th of April, 2020, is a global pandemic taking a big hit on individuals, families, communities and societies around the world (Vasantha Raju and Patil, 2020). Ever since it began, there has been daily loss of lives, falling of economies leading to recession and changes observed in the

(C) M. Mahima, R. Shanthi Priya, Prashanthini Rajagopal and C. Pradeepa. Published in Frontiers in Engineering and Built Environment. Published by Emerald Publishing Limited. This article is published under the Creative Commons Attribution (CC BY 4.0) licence. Anyone may reproduce, distribute, translate and create derivative works of this article (for both commercial and non-commercial purposes), subject to full attribution to the original publication and authors. The full terms of this licence may be seen at http://creativecommons.org/licences/by/4.0/legalcode.

The authors would like to thank SRM Institute of Science and Technology, the co-authors for the continued assistance in finalizing this article.

Conflict of interest: The author(s) declared no potential conflicts of interest with respect to the research, authorship and/or publication of this article.
Impact of

Covid-19 on

built

environment

69

Received 7 September 2021 Revised 9 October 2021 17 December 2021

Accepted 8 January 2022

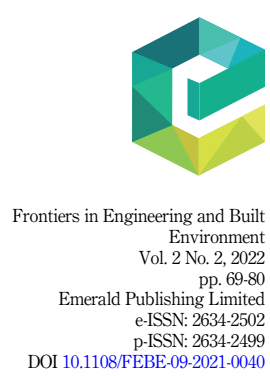


FEBE

2,2

70

traditional, social and economic activities and public health safety. With various variants of SARS-CoV-2 spreading around various parts of the world, some with increased transmissibility, it is necessary to drastically improve preparedness, readiness and response actions (Bhouri et al., 2021).

Covid-19 that was found to be different from diseases caused by coronaviruses like Middle East Respiratory Syndrome (MERS) and Severe Acute Respiratory Syndrome (SARS), was also found to spread rapidly and that the outbreaks could grow at an exponential rate (Krauskopf, 2020). The clinical fatality on an average was 3\% and was seen to increase with age at approximately $15 \%$ rate or higher in people above 80 . Comorbidities associated with respiratory, cardiovascular and immune systems increase the risk of the severity of an illness or even death.

A psychological result of Covid-19 is aversion to big crowds. People may have to change their habits in order due to the restrictions imposed on them because of the pandemic. Many public spaces would have to be rearranged and reorganized to accommodate a lesser crowd to reduce transmission risk. There might be a necessity for a change in the regulatory norm as some distances and dimensions are shorter than the recommended physical distancing norms (Honey-Rosés, 2020; Lake et al., 2021).

WHO suggested how everybody could contribute in mitigating Covid-19. Individuals could protect themselves and their first circles by following all government norms including washing hands, not touching their faces, adopting respiratory practices, maintaining physical distance, isolation of oneself when there are doubts of showing Covid-19 symptoms, etc.

Communities should come together and help each other to feel empowered. Government should lead and coordinate among all its citizens to own the response by engaging, educating and supporting. It should also implement norms and regulations to be followed by people in public and crowded places over and above maintaining and improving health and social services available to people.

Urban public spaces like superstores, wholesale markets, have been hotspots for transmission of Covid-19. This is predominantly because physical distancing norms have been difficult to be followed in places inviting large crowds. These places hardly provide adequate space for all necessary stakeholders and their dependent activities to fit in.

Especially in heavily dense countries where markets, mandis and bazaars are clogged with an oversaturation of people, it is close to impossible to make people follow all the public norms and regulations for Covid-19 mitigation. Shutting these places down until after the pandemic is out of the picture considering how the economy of the market would collapse with no activity.

In one of India's southern states, Tamil Nadu, $35 \%$ of the Covid-19 cases was contributed by one of its major wholesale markets that transported goods to and from various different wholesale markets in different parts of Tamil Nadu. After the first lockdown in Tamil Nadu, the market reopened about 200 of its wholesale vegetable shops leading to about 3,000 cases from just the cluster in a couple of months. Alternate options were made to quickly mitigate the transmission of the virus by transferring part of the crowd to another locality on the outskirts of the city but failed to impress the traders due to lack of convenience.

Such situations call for better designing and planning methodologies. It also highlights the necessary for considering and spreading awareness on post-pandemic behaviors in public spaces.

Although short term strategies like individual hygiene, community activities, etc. were made, involving such strategies into the design in advance would help decrease the transmission of such communicable diseases in the future.

\section{Methodology}

Various research journals from Science Direct and Taylor and Francis among others were referred and reviewed to learn more on Covid-19 along with its impacts on people and their 
built environment. Figure 1 shows the flowchart of the methodology followed. Keywords that aligned with the topic of interest like pandemic, Covid-19, coronavirus, urban spaces, built environment, built-up space were identified. Research papers that aligned with the scope of the paper and its keywords were found as in Figure 2. An excel sheet with the basic data of these papers was written down. The essence of each of these articles were understood and linked with the topic in hand. A review of all these papers was written coherently to the topic. Future scope in this field of study was also identified.

\section{Literature review}

\subsection{Covid-19 and physical distancing}

The pandemic has seen a lot of changes in public places (Hanzl, 2020; Lake et al., 2021). In the first place, pandemics even demand lockdowns because urban spaces could not cater to the mitigation norms and regulations that were expected of the public to follow as these public spaces were not designed keeping in mind these requirements (Allam and Jones, 2020). Social distancing has been imposed in urban spaces by introducing markers like tape, painted grass, cutting of grass, etc. (Hanzl, 2020).

Covid-19 has been looked up as a design problem. The physical distancing norm of 6 feet has been questioned about whether it would be enough considering aerosols and the viruses settled over other surfaces (Megahed and Ehab, 2020). Planning and designing norms might have to be reiterated keeping in mind the new normal post a pandemic like Covid-19. Equal accessibility and availability of public spaces is not an assurance that comes out of redesigning and reimagining public spaces. However, the needs of such vulnerable groups can be put in front as an environmental justice priority (Honey-Rosés, 2020).
Identification of the topic

Identifying keywords

related to the topic

Finding papers on the topic using the keywords

Framing summaries for the papers identified

Compiling them together and analysing the summaries

Concluding on the derived measures that might work to stop the spread of Covid-19
Impact of Covid-19 on built environment 
FEBE

2,2

72

Figure 2 .

Journals identified

\begin{tabular}{|c|c|c|c|c|c|c|}
\hline S NO & ARTICLE TITLE & AUTHOR(S) & YEAR & JOURNAL & KEYWORDS & PUBLICATIONS \\
\hline & $\begin{array}{l}\text { Antivirus-built environment: } \\
\text { Lessons learned from Covid-19 } \\
\text { pandemic }\end{array}$ & Naglaa A. Megahed, Ehab M. Ghoneim & 2020 & $\begin{array}{l}\text { Sustainable } \\
\text { Cities and } \\
\text { Society }\end{array}$ & $\begin{array}{l}\text { Anti virus, Architecture, Built environment, COVID } \\
\text { 19, Social distancing, Post pandemic Urbanism }\end{array}$ & ELSEVIER \\
\hline & $\begin{array}{l}\text { Are high-density districts more } \\
\text { vulnerable to the COVID-19 } \\
\text { pandemic? }\end{array}$ & $\begin{array}{l}\text { Amir Reza Khavarian-Garmsir, Ayyoob Sharifi, } \\
\text { Nabi Moradpour }\end{array}$ & 2021 & $\begin{array}{l}\text { Sustainable } \\
\text { Cities and } \\
\text { Society }\end{array}$ & $\begin{array}{l}\text { COVID-19, Density, Risk factors, Compact city, } \\
\text { Tehran }\end{array}$ & ELSEVIER \\
\hline 3 & $\begin{array}{l}\text { Pandemic and the planning of } \\
\text { resilient cities and regions }\end{array}$ & Reza Banai & 2020 & Cities & $\begin{array}{l}\text { Cities, Regions, Pandemic, Coronavirus, Climate } \\
\text { change, Public health, Public realm, Urban } \\
\text { system, Resilience, Sustainability, Urban form, } \\
\text { Comprehensive plan }\end{array}$ & ELSEVIER \\
\hline & $\begin{array}{l}\text { Pandemic stricken cities on } \\
\text { lockdown. Where are our planning } \\
\text { and design professionals [now, } \\
\text { then and into the future]? }\end{array}$ & Zaheer Allam \& David S Jones & 2020 & Land Use Policy & $\begin{array}{l}\text { Pandemic; COVID-19; Resilience; Cooperation; } \\
\text { Cities; Urban Economy; Health Policy; Design } \\
\text { Institutes; Smart City; Urban Planning; Resilience }\end{array}$ & ELSEVIER \\
\hline & \begin{tabular}{|l|} 
Revisiting the built environment: \\
10 potential development \\
changes and paradigm shifts due \\
to COVID-19
\end{tabular} & Ali Cheshmehzangi & 2021 & $\begin{array}{l}\text { Journal of Urban } \\
\text { Management }\end{array}$ & $\begin{array}{l}\text { Development changes, Paradigm shift } \\
\text { Construction, Built environment, Resilience, } \\
\text { CoVID-19 }\end{array}$ & ELSEVIER \\
\hline & $\begin{array}{l}\begin{array}{l}\text { Activity-friendly neighbourhoods } \\
\text { can benefit non-communicable } \\
\text { and infectious diseases }\end{array} \\
\end{array}$ & Deepti Adlakha \& James F. Sallis & 2020 & Cities \& Health & COVID-19; physical activity; density & $\begin{array}{l}\text { ROUTLEDGE - } \\
\text { TAYLOR \& } \\
\text { FRANCIS }\end{array}$ \\
\hline & $\begin{array}{l}\text { From one pandemic to another: } \\
\text { emerging lessons from COVID-19 } \\
\text { for tackling physical inactivity in } \\
\text { cities }\end{array}$ & $\begin{array}{l}\text { Craig W. McDougall, Caroline Brown, Craig } \\
\text { Thomson, Nick Hanley, Mark A. Tully, } \\
\text { Richard S. Quilliam, Phil J. Bartie , Lesley } \\
\text { Gibson \& David M. Oliver }\end{array}$ & 2020 & Cities \& Health & $\begin{array}{l}\text { Physical activity, Neighbourhood inequality, Urban } \\
\text { planning }\end{array}$ & $\begin{array}{l}\text { TAYLOR \& } \\
\text { FRANCIS }\end{array}$ \\
\hline & $\begin{array}{l}\text { The impact of COVID- } 19 \text { on public } \\
\text { space: an early review of the } \\
\text { emerging questions - design, } \\
\text { perceptions and inequities }\end{array}$ & $\begin{array}{l}\text { Jordi Honey-Rosés, Isabelle Anguelovski, } \\
\text { Vincent K. Chirehd, Carolyn Dahere, Cecil } \\
\text { Konijnendijk van den Bosch, Jill S. Litt, Vrushti } \\
\text { Mawani, Michaeel K. McCallh, Arturo Orellanai, } \\
\text { Emilia Oscilowicza, Ulises Sánchezj, Maged } \\
\text { Senbela, Xueqi Tank, Erick Villagomeza, Oscar } \\
\text { Zapata and Mark J Nieuwenhuijsene } \\
\end{array}$ & 2020 & Cities \& Health & COVID-19; design; planning; public space & $\begin{array}{l}\text { ROUTLEDGE - } \\
\text { TAYLOR \& } \\
\text { FRANCIS } \\
\end{array}$ \\
\hline & $\begin{array}{l}\text { The new proxemics: COVID-19, } \\
\text { social distancing, and sociable } \\
\text { space }\end{array}$ & Vikas Mehta & 2020 & \begin{tabular}{|l|} 
Journal of Urban \\
Design
\end{tabular} & & $\begin{array}{l}\text { ROUTLEDGE - } \\
\text { TAYLOR \& } \\
\text { FRANCIS } \\
\end{array}$ \\
\hline 10 & $\begin{array}{l}\text { Urban forms and green } \\
\text { infrastructure - the implications for } \\
\text { public health during the COVID-19 } \\
\text { pandemic }\end{array}$ & Małgorzata Hanzl & 2020 & Cities \& Health & $\begin{array}{l}\text { Public health; urban form; ecosystem services; } \\
\text { COVID-19; pandemic; green infrastructure }\end{array}$ & $\begin{array}{l}\text { ROUTLEDGE - } \\
\text { TAYLOR \& } \\
\text { FRANCIS } \\
\end{array}$ \\
\hline 11 & $\begin{array}{l}\text { COVID-19 dynamics across the } \\
\text { US: A deep learning study of } \\
\text { human mobility and social } \\
\text { behavior }\end{array}$ & \begin{tabular}{|l} 
Mohamed Aziz Bhouri, Francisco Sahli \\
Costabal, Hanwen Wang, Kevin Linka, \\
Mathias Peirlinck, Ellen Kuhl, Paris Perdikaris
\end{tabular} & 2021 & \begin{tabular}{|l|} 
Computer \\
Methods in \\
Applied \\
Mechanics and \\
Engineering \\
\end{tabular} & $\begin{array}{l}\text { Epidemiology model discovery; Sensitivity } \\
\text { analysis; Neural networks; Scientific machine } \\
\text { learning; Dynamical systems; Uncertainty } \\
\text { quantification }\end{array}$ & ELSEVIER \\
\hline 12 & $\begin{array}{l}\text { Addressing the public mental } \\
\text { health challenge of COVID-19 }\end{array}$ & $\begin{array}{l}\text { Jonathan Campion, Afzal Javed, Norman } \\
\text { Sartorius, Michael Marmot } \\
\end{array}$ & 2020 & PlumX Metrics & & $\begin{array}{l}\text { THE LANCET } \\
\text { PHYCHIATRY }\end{array}$ \\
\hline 13 & $\begin{array}{l}\text { The Economy on lce: Meeting the } \\
\text { Economic Challenges during and } \\
\text { after the COVID-19 Crisis }\end{array}$ & Spiros Bougheas & 2020 & & COVID-19, Central Bank Policy, Incomes Policy & SSRN \\
\hline 14 & $\begin{array}{l}\text { Does Density Aggravate the } \\
\text { COVID-19 Pandemic? }\end{array}$ & Shima Hamidi,Sadegh Sabouri, Reid Ewing & 2020 & \begin{tabular}{|l} 
Journal of the \\
American \\
Planning \\
Association \\
\end{tabular} & $\begin{array}{l}\text { COVID-19, density, infectious diseases, pandemic, } \\
\text { urban sprawl }\end{array}$ & $\begin{array}{l}\text { ROUTLEDGE - } \\
\text { TAYLOR \& } \\
\text { FRANCIS }\end{array}$ \\
\hline 15 & $\begin{array}{l}\text { World Health Organization } \\
\text { Academy: COVID-19 Learning } \\
\text { and WHO } \\
\text { Info Mobile Apps }\end{array}$ & Patricia Biller Krauskopf & 2020 & $\begin{array}{l}\text { The Journal for } \\
\text { Nurse } \\
\text { Practitioners }\end{array}$ & & ELSEVIER \\
\hline 16 & $\begin{array}{l}\text { Indian Publications on SARS- } \\
\text { CoV-2: A bibliometric study of } \\
\text { WHO COVID-19 database }\end{array}$ & Vasantha Raju N, S.B.Patil & 2020 & \begin{tabular}{|l} 
Diabetes \& \\
Metabolic \\
Syndrome: \\
Clinical \\
Research \& \\
Reviews \\
\end{tabular} & $\begin{array}{l}\text { COVID-19, SARS-CoV-2, India, Bibliometrics, } \\
\text { WHO COVID-19 database }\end{array}$ & ELSEVIER \\
\hline 17 & $\begin{array}{l}\text { Public health challenges during } \\
\text { the COVID-19 outbreak in Nepal: } \\
\text { a commentary }\end{array}$ & Sharmistha Sharma, Jeevan Bhatta & 2020 & \begin{tabular}{|l} 
Journal of Health \\
Research
\end{tabular} & & ELSEVIER \\
\hline 18 & $\begin{array}{l}\text { COVID-19: Real-time } \\
\text { dissemination of scientific } \\
\text { information to fight a public health } \\
\text { emergency of international } \\
\text { concern }\end{array}$ & Peipei Song, Takashi Karako & 2020 & $\begin{array}{l}\text { National Library } \\
\text { of Medicine }\end{array}$ & $\begin{array}{l}\text { 2019-nCoV; COVID-19; SARS-CoV-2; sharing } \\
\text { data }\end{array}$ & PUBMED \\
\hline 19 & $\begin{array}{l}\text { COVID-19 false dichotomies and } \\
\text { a comprehensive review of the } \\
\text { evidence regarding public health, } \\
\text { COVID-19 symptomatology, } \\
\text { SARS-CoV-2 transmission, mask } \\
\text { wearing, and reinfection }\end{array}$ & $\begin{array}{l}\text { Kevin Escandón, Angela L Rasmussen, Isaac I } \\
\text { Bogoch, Eleanor J Murray, Karina Escandón, } \\
\text { Saskia V Popescu, Jason Kindrachuk }\end{array}$ & 2021 & $\begin{array}{l}\text { National Library } \\
\text { of Medicine }\end{array}$ & $\begin{array}{l}\text { Aerosol; Asymptomatic; COVID-19; Coronavirus; } \\
\text { Droplet; Harm reduction; Mask; } \\
\text { Nonpharmaceutical intervention; Outdoor; } \\
\text { Pandemic; Pollution; Presymptomatic; Reinfection; } \\
\text { SARS-CoV-2; Transmission }\end{array}$ & PUBMED \\
\hline
\end{tabular}

\subsection{Covid-19 in urban public spaces}

While talking about the built environment, the spaces that balance these out, the urban open spaces play a very important role in the smooth functioning of built spaces. A pandemic shows how the architectural practices in some countries are incapable of accommodating the pandemic procedures and measures suggested and followed. The pandemic exposes the vulnerability and resilience of an urban system. This throws more light into the necessity for the clear distinction between a space and a place (Banai, 2020).

A place gives more definition to the circulation pattern and functioning of a place hence restricting the movement of the people within it. This further helps reduce the spread of the virus when compared with a space where there is chaotic movement of people. This also helps in bringing up ideas for a resilient urban planning in the future (Banai, 2020). Services in an 
urban ecosystem that indirectly influence the activities in a place need to consider the urban fabric, it's form, density, parcellation of land, heights, volume distribution and it's open spaces (Hanzl, 2020). This influences the movement of people and the activities happening in the place. These activities determine the spread of the virus in that place.

Inclusive urban planning and proper management of multi-functional public spaces over preventive design strategies could encourage and enable physical activity by designing for the future (McDougall et al., 2020; Honey-Rosés, 2020).

Covid-19 is not the first virus to stir the urban scenario to a large extent. Multiple research has been made before on how high densely populated urban areas might pave the way for easier transmission of communicable diseases due to higher rates of social contact among its residents (Khavarian-Garmsir et al., 2021). Starting from Black Death and Spanish flu to tuberculosis, yellow fever, cholera, measles, typhus, typhoid, smallpox, leprosy, malaria and the consequences on the city's built environment predominantly pointed toward the issue of densifying an area with oversaturated population with people living in closeness, proximity to each other (Allam and Jones, 2020).

Milan 2020 and "Paris en commune" are two programs trying to achieve the objective of "15 minute cities" post pandemic where all amenities are at an accessible distance of $15 \mathrm{~min}$ walking distance. This distributes the buyer crowd across the city (Hanzl, 2020). Singapore was applauded for its lockdown strategy, but this turned out to be flawed even with the best measures taken (Hodge, 2020; Allam and Jones, 2020).

Covid-19 has changed the idea of public space (Gehl and Svarre, 2013; Sadik-Kahn and Solomonow, 2017; Lake et al., 2021). Once we walk out of our houses, we experience distant and unfamiliar social relations. This makes us speculate about how social interactions are changing in these spaces. Public space is expected to have a paradigm shift that will create opportunities that help processing activities that were previously impossible by making them necessary and feasible. As people try to avoid the peak hour rush, retail spaces, parks, public transport, etc. will see the rationing of its time (Honey-Rosés, 2020).

Urban public realms have been put to use in ways unforeseen or unimagined by its urban planners and designers. People used to come out to public realms and interact with other fellow citizens. But with Covid-19 making social lives next to impossible, physical inactivity has been a very common phenomenon. This has also decreased the immunity of people hence making them more prone to diseases than before (McDougall et al., 2020; Honey-Rosés, 2020).

The impacts of the pandemic have not just been seen on public health but have also impacted the socio-economic composition of cities (Foletti, 2020; Campion et al., 2020; Sharma and Jeevan, 2021; Muhammad, 2020; Bougheas, 2020; Rashid et al., 2020). This increases the need to redefine disaster management norms when it comes to biological disasters. Communities are to be designed keeping in mind their inclusivity, safety, resilience and sustainability (Allam and Jones, 2020). Some design based suggestions to accommodate both public health and economic factors that influence the lives of people are adaptations in compact design to bring about more circulation in between built environments, deducing the density in a particular radius, smaller internal layouts or smaller super blocks to include more streets around them, spatial planning considerations to alleviate movement of people, attention to spatial level of built environment to decongest and spread population, noncentralized building systems to encourage people to more, etc. (Cheshmehzangi, 2020a, 2021).

Some older methodologies also prove to be more useful in current times. Urban approaches like horizontal expansion, decentralization, de-densifying cities, urban farming, lesser motorized vehicles and increased pedestrian and cycling facilities, self-sufficient strategies, more green pockets, low-rise buildings, adaptive reuse, hygienic, lightweight, adaptable building materials, etc., are some means to help curb the spread of Covid-19 (Megahed and Ehab, 2020).

\section{Impact of Covid-19 on built environment}


FEBE

2,2

Geospatial data showed that workers with a lower income moved around during the pandemic, while workers with a higher income worked from their houses. With communicable diseases making rounds, differences based on class, income or educational qualification might not exist in public spaces (Honey-Rosés, 2020).

The research article on high-density districts being more vulnerable to the COVID-19 (Khavarian-Garmsir et al., 2021), based on the results obtained from an Iranian app to mitigate the spread of Covid-19, showed the difference in urban infrastructure within districts depending on the predominant income of the residents in that district. This was also reflected in the morbidity rate of Covid-19 depending on the density of the district. Older people took part in more interactions leading to increased transmission rates among them. Men showed to be more prone to acquiring the virus due to gender based differences in life habits. Although it is speculated that educated individuals will have more awareness about the effects of Covid19 and hence will adhere to the rules and regulations put down, it was not the case in this experiment. People chose to take the riskier way of public transportation over private vehicles because of their affordability. Higher income was prevalent in districts with high employment opportunities (Khavarian-Garmsir et al., 2021).

The research paper on a study conducted in Bangladesh concludes that zone-based lockdown would be the best option to suppress Covid-19 and outbreak and prevent further spreading (Islam et al., 2020a, b). This is true not only in the case of Bangladesh but is true for other countries where the pandemic cannot be managed with expecting people to be responsible.

The necessity of the hour is to make corrections to architectural and urban design institutions to include pandemic influenced consequences into the curriculum to make future architects and designers well prepared for such situations (Allam and Jones, 2020).

\subsection{Covid-19 and neighborhoods}

Neighborhood public spaces that promote social interactions provide health and sociopsychological benefits. Streets in a neighborhood should be reconsidered as active and social spaces (Mehta, 2020). Social distancing has transformed lives and made it more difficult. With the pandemic forcing people to spend more time within the neighborhood, the use of spaces and its social activities have changed (Mehta, 2020).

With Covid-19 constantly challenging our everyday lives, short term interventions like lockdown and work from home have been introduced that led to decreased commuting and reduced traffic (Hanzl, 2020).

Covid-19 has eventually changed the preferences of people. Lesser pedestrians prefer walking and this will eventually lead to change in neighborhoods (Honey-Rosés, 2020). Our social behaviors will also change (Honey-Rosés, 2020). An indication of a public space being healthy and functioning is the existence of people in that space (Gehl and Svarre, 2013; SadikKahn and Solomonow, 2017).

People have started preferring smaller urban open spaces that people within a locality use over larger ones that bring in a wider population from places further away from them. Having access to nature has proven to be both physically and mentally beneficial (Velarde et al., 2007; Honey-Rosés, 2020).

As shopping in person is out of the question now, online shopping has taken the limelight. This demands more thought into the designing of frontages of houses and communities and delivery happens out here (Honey-Rosés, 2020; Lake et al., 2021).

Contrary to initial understanding, density was not the key factor determining the spread of the virus. Average income and the age group of residents also determine the level of transmission in that district. Suggestions by the researchers included policymakers considering the area under discussion and its prevalent conditions before framing policies for it. Neighborhood-oriented development patterns should be encouraged. Especially in 
areas with lower levels of employment which proved to be more vulnerable (KhavarianGarmsir et al., 2021).

Although new proxemics as defined by Edwar T Hall, an American anthropologist and cross-cultural researcher, has brought in new social distancing methodologies; stay at home orders can be difficult on people in neighborhoods with less or no access to public spaces nearby or private open spaces. For some, this time means coercively liking being outside while it translates into enduring indoors or taking enormous risks for some others (Mehta, 2020). While some of us are not allowed to be in public unless there is an emergency, others get to enjoy parks and green spaces.

\subsection{Covid-19 and streets}

In Edwar T Hall's words, "Streets have transformed from sociofugal to sociopetal spaces." (Mehta, 2020). "Proxemics" as defined by Edwar T Hall, establishes that the range of social behavior is determined by the distance and the relationship of humans with each other. Hall, unlike the general connotation of social distancing that implies staying away, defines social distancing in a way to create a new sociable space. Covid-19 has led to increased social and physical activities in neighborhoods around the world. Newer activities and modified spaces increase social interaction within a limited circle. Social distancing in many neighborhoods has delivered a new sociable space (Mehta, 2020).

The change in our preference for open spaces with exposure to a pandemic makes it necessary for designers to consider physical distancing while designing. Wider trails and walkways are necessary (Velarde et al., 2007; Honey-Rosés, 2020). Many cities have considered making sidewalks broader and re-designing pedestrian crossings to increase social activity keeping in mind the physical distancing norms. In India, we have seen social distancing in public places imposed on people by marking yellow circles at a distance of six feet from each other.

\subsection{Covid-19 and green spaces}

More greenery along streets, more bicycle and pedestrian facilities also were game changers as they helped follow the public norms and encouraged people to walk without having to share their personal space with a stranger (Hanzl, 2020).

Community gardens have an additional advantage over other spaces contributing to the urban fabric as they are flexible to the policies on physical distancing and also ensure a social and emotional connection between the people who use the space (Honey-Rosés, 2020).

Parks, green spaces, trails and other public spaces have been looked down at ever since Covid-19 started. Shutting down these places completely might not be the wisest decision. Instead there must be awareness and close monitoring of these places to avoid spread of the virus. Recommendations are walkable, activity-friendly urban design with modifications depending on the place of implementation to mitigate the spread of such infectious diseases (Sallis et al., 2020; Escandón et al., 2021). Intermixing of public realm, social spaces and green infrastructure that contain heritage parks, parklets, waterfronts, pocket parks, community/allotment gardens, neighborhood parks, street vegetation, informal vegetation, vertical gardens, rooftop gardens and private gardens considering various factors has led to an ecosystem of measures at a neighborhood scale (Hanzl, 2020; Honey-Rosés, 2020).

Covid-19 has also done a lot of positive impacts on the environment. This should be utilized to create an environment where the built space goes hand in hand with the surrounding and yet helps curb the spread of Covid-19. Research from Bangladesh shows that meteorological air quality indicator values have dropped ever since the full lockdown was initiated. This shows how enforcing the rule makes people follow it whereas making it optional only makes it
Impact of Covid-19 on built environment 
FEBE

2,2

76 easier to evade the rule. It also shows how the change in the activities of people changes the meteorological aspects of the location (Rahman et al., 2020; Islam et al., 2020a).

\subsection{Covid-19 and transportation}

Covid-19 has enabled people to be very careful while moving about in public. This involves avoiding public transportation for the fear of unknowingly coming across a carrier of the virus. People have started turning down traveling to stay at home for the fear of compromising their health and safety.

With the pandemic forcing people to stay indoors, online shopping has seen a big leap with people preferring online shopping over in-person purchases. Even the ones, who try to go out to buy, prefer private vehicles over shared ones. More green pockets can be introduced along with provisions for pedestrians and cyclists to reduce the dependency of people on motorized vehicles. This will also encourage people getting out of homes to buy rather than buying online.

From the examples quoted in this study of the different measures taken all around the world, we can argue that these design recommendations once implemented could go both ways. The change will be gradual and might take a lot of time to come up with long term solutions that might work. Multiple iterations might also be needed to find the ideal solution. This study's design recommendations should be viewed largely as food for thought of future development modifications in the built environment, which we anticipate.

Soon enough, post pandemic architecture and urbanism might have its own separate style given how demanding the virus is on the built environment (Megahed and Ehab, 2020). Professionals in the making might need a better insight into post-pandemic and resilient architecture to prepare for all future pandemics.

\section{Discussions and recommendations}

The scholarly discussion on these research papers that discuss in detail about the impact and design considerations to be made for mitigation and prevention of Covid-19 in built spaces conclude that on a city scale, promoting development horizontally, maintaining lower density, decentralization, urban farming, encouraging fewer motorized vehicles and more cycling and walking facilities on top of easily accessible public transit systems with considerations given to physical distancing norms, distribution of green by designing more green pockets over large green patches, low-rise buildings, adaptive reuse can help curb the spread of a communicable disease at an urban level by practicing self-sufficient strategies during the designing stage. Intermixing of public realms, social spaces and green infrastructure that contain heritage parks, parklets, waterfronts, pocket parks, community gardens, allotment gardens, neighborhood parks, street vegetation, informal vegetation, vertical gardens, rooftop gardens and private gardens also help redistributing population by avoiding crowded neighborhoods. Inclusive urban planning and proper management of multi-functional public spaces over preventive design strategies could encourage and enable physical activity which leads to people having a sedentary lifestyle and lower immunity levels that make them prone to a large number of diseases.

On a smaller scale, in districts, wider trails and walkways, smaller urban open spaces encourage more pedestrians despite the pandemic as public spaces seem to be safe by allowing physical distance. Hygienic, lightweight and adaptable building materials can be preferred to achieve smarter buildings in a neighborhood. Neighborhood-oriented development in places that contain a mixture of people based on socio-economic grounds can promote community development as a whole by providing inclusivity, safety, resilience and sustainability. 
Throwing more light onto the effects of the pandemic on public spaces in countries with a dense population like India, many public spaces that have been used to having large gatherings of people congregating in parks, grounds, large commercial spaces like malls, markets, bazaars or mandis, etc., for political speeches, concerts, religious meetings, marriages among many other occasions fail to help in mitigating the spread of the virus. This is majorly contributed by the fact that these places are almost completely dependent on the physical presence of people for its running.

A complete lockdown until the virus ceases to exist seems very impossible as the downfall of the economy of the country affects every individual living in it. This increases the need to come up with solutions to design and build spaces that will be able to withstand futuristic communicable diseases as well and not require it's shutting down to mitigate the pandemic.

When it comes to the field of urban design, revisions in compact design, considerations to density, smaller internal layouts, spatial planning considerations like placemaking to public place design smaller and individual internal layouts, considerations to spatial level of built environment and non-centralized building systems can bring in more social interaction with lesser fear of virus transmission. Design recommendations by researchers, architects and urban planners can be included into future designs of urban spaces. An insight on past measures and futuristic recommendations to reduce the effects of pandemics in the future could be included into the curriculum of architecture, urban planning and designing to help budding professionals in understanding and building pandemic-resistant urban spaces to face the pandemics of the future.

Despite multiple research and speculations made on how to mitigate the impact of Covid-19, it is still an evolving crisis hence making it close to impossible to make conclusions that will work undoubtedly. When it comes to specific built spaces like wholesale markets, mandis, markets, etc., there is a lot of scope for future research.

Looking into the pandemic effects in countries where some of the measures have failed to be successful, the need of the hour is to prevent the further spread of the virus. This necessarily needs a lot of understanding about the functioning of the place along with the beliefs, practices and culture of the people in it. Any measure that violates or restricts their activities on a large scale will be disregarded and broken. Every measure taken by the respective authorities should be taken having in mind the implications of the same in the city or country it is being implemented in.

\section{Conclusion}

Mitigation strategies to prevent the spread of Covid-19 in existing built forms have been discussed and analyzed. Reducing the spread of the existing virus is one part of the strategies for eradicating Covid-19 and its effects. Prevention in the future is another major part that helps prevent the spread of the virus to new communities.

These mitigation and prevention strategies can be successful on implementation only if the users, the people, vouch to maintain and follow the Covid-19 protocols of maintaining six feet distance at all times and other health protocols. It is psychologically difficult to make people follow a rule that can be broken. The fear of death increases with every addition loss of life. This changes the habit of misusing the rule or breaking the rule.

The future of built environment should be planned and designed in such a way so as to accommodate these mitigation strategies and provide an easy way to follow the public health protocols not only to prevent the spread of Covid-19 but also prevent the spread of other communicable diseases.

Urban spaces should facilitate social distancing. Social gathering spaces with active interaction of people should be broken up into pocket spaces. This reduces congestion and
Impact of Covid-19 on built environment

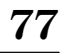


FEBE

2,2

78

spreads people across these spaces. These pocket spaces should be designed keeping in mind the spread of the virus and hence the public health protocols.

Although several policies and measures have been taken, not all of them turn out to be successful in all locations of implementation. Depending on the density of people, cultural practices, acceptance and awareness of people, etc., the success rates of these policies change. The understanding of the essence of the location and the awareness for understanding and acceptance of policies among the common public is very vital. For example, social distancing in developed cities with well-designed wide sidewalks is possible whereas in developing or under-developed cities, the presence of wide sidewalks that support social distancing. Awareness among the public about the new spatial reforms that have been implemented in public spaces will be less in rural areas compared to urban areas. Systematic divisioning and sectoring of public spaces will only be a success if people.

\section{Future scopes}

Governance has become a key challenge in many countries, and not that much research is conducted on pandemic governance and needs to be considered as a core research gap (Zhang and Rajib, 2020). With Covid-19 being an ongoing pandemic, new discoveries about the virus have been made every day. The mitigation and prevention strategies discussed in this paper aid the prevention and mitigation of the virus based on what we know of the virus in the current world. This paves the way for futuristic studies on the coronavirus with more revelations being discovered about the virus. Covid-19 can also be studied as a pandemic case study to understand pandemics and prevent pandemics in the future.

\section{Limitations}

The limitation of this study is the restricting of the study of Covid-19 to only architectural, urban and public realm scales. The study does not facilitate the involvement of other fields and their influence with Covid-19.

\section{References}

Allam, Z. and Jones, D.S. (2020), "Pandemic stricken cities on lockdown. Where are our planning and design professionals [now, then and into the future]?", Land Use Policy, Pergamon, available at: www.sciencedirect.com/science/article/abs/pii/S0264837720305974.

Banai, R. (2020), "Pandemic and the planning of resilient cities and regions", Cities, Pergamon, available at: www.sciencedirect.com/science/article/abs/pii/S0264275120312774.

Bhouri, M.A., Costabal, F.S., Wang, H., Linka, K., Peirlinck, M., Kuhl, E. and Perdikaris, P. (2021), "COVID-19 dynamics across the US: a deep learning study of human mobility and social behavior", Computer Methods in Applied Mechanics and Engineering, [online], Vol. 382, p. 113891, available at: http://www.sciencedirect.com/science/article/abs/pii/S0045782521002280.

Bougheas, S. (2020), "The economy on ice: meeting the economic challenges during and after the Covid-19 crisis", SSRN, available at: papers.ssrn.com/sol3/papers.cfm?abstract_id=3563536.

Campion, J., Javed, A., Sartorius, N. and Marmot (2020), "Addressing the public mental health challenge of Covid-19", The Lancet. Psychiatry, U.S. National Library of Medicine, available at: https://pubmed.ncbi.nlm.nih.gov/32531299/.

Cheshmehzangi, A. (2020), "10 adaptive measures for public places to face the COVID 19 pandemic outbreak", City and Society, Vol. 32 No. 2.

Cheshmehzangi, A. (2021), "Revisiting the built environment: 10 potential development changes and paradigm shifts due to Covid-19", Journal of Urban Management, Elsevier, available at: www. sciencedirect.com/science/article/pii/S2226585621000054. 
Escandón, K., Rasmussen, A.L., Bogoch, I.I., Murray, E.J., Escandón, K., Popescu, S.V. and Kindrachuk, J. (2021), "COVID-19 false dichotomies and a comprehensive review of the evidence regarding public health, COVID-19 symptomatology, SARS-CoV-2 transmission, mask wearing, and reinfection", BMC Infectious Diseases, Vol. 21 No. 1.

Foletti, A. (2020), "Some biophysical perspectives on the Covid-19 health challenge", Conference on the Mechanism of Covid-19 Virus Protein Spikes Interaction with Host Cell Membrane and Its Agedependency, UNESCO/UNITWIN Interregional Network on "Biophysics, Biotechnology and Environmental Health control”, Yerevan, Armenia, Yerevan, Armenia.

Gehl, J. and Svarre, B. (2013), How to Study Public Life, Island Press, Washington, DC, available at: https://islandpress.org/books/how-study-public-life.

Hanzl, M. (2020), Urban Forms and Green Infrastructure - the Implications for Public Health during the COVID-19 Pandemic, Taylor \& Francis, available at: https://www.tandfonline.com/doi/full/10. 1080/23748834.2020.1791441.

Hodge, A. (2020), "Singapore faces up to shutdown reality", The Australian.

Honey-Rosés, J. (2020), The Impact of Covid-19 on Public Space: An Early Review of the Emerging Questions - Design, Perceptions and Inequities, Taylor \& Francis, available at: https://www. tandfonline.com/doi/full/10.1080/23748834.2020.1780074.

Islam, A.R.M.T., Hasanuzzaman, M., Shammi, M., Salam, R., Bodrud-Doza, M., Rahman, M.M., Mannan, M.A. and Huq, A.R., , (2020a), "Are meteorological factors enhancing COVID-19 transmission in Bangladesh? Novel findings from a compound Poisson generalized linear modeling approach”, Environmental Science and Pollution Research, Vol. 28 No. 9, pp. 11245-11258, doi: 10.1007/s11356-020-11273-2.

Islam, A.R.M.T., Hasanuzzaman, M., Azad, M.A.K., Salam, R., Toshi, F.Z., Khan, M.S.I., Alam, G.M.M. and Ibrahim, S.M., (2020b), "Effect of meteorological factors on Covid-19 cases in Bangladesh", Environment, Development and Sustainability, Vol. 23 No. 6, pp. 9139-9162, doi: 10.1007/s10668020-01016-1.

Khavarian-Garmsir, A.R., Sharifi, A. and Moradpour, N. (2021), "Are high-density districts more vulnerable to the COVID-19 pandemic?”, Sustainable Cities and Society, Vol. 70, p. 102911.

Krauskopf, P.B. (2020), "World health organization academy: Covid-19 learning and WHO info mobile apps", The Journal for Nurse Practitioners, Elsevier, available at: https://www.npjournal.org/ article/S1555-4155(20)30382-2/pdf.

Lake, J., Gerrans, P., Sneddon, J., Attwell, K., Botterill, L. and Lee, J. (2021), "We're all in this together, but for different reasons: social values and social actions that affect COVID-19 preventative behaviors", Personality and Individual Differences, p. 110868.

McDougall, C.W., Brown, C., Thomson, C., Hanley, N., Tully, M.A., Quilliam, R.S., Bartie, P.J., Gibson, L. and Oliver, D.M. (2020), "From one pandemic to another: emerging lessons from COVID-19 for tackling physical inactivity in cities", Cities and Health, pp. 1-4.

Megahed, N.A. and Ehab, M.G. (2020), "Antivirus-built environment: lessons learned from Covid-19 pandemic", Sustainable Cities and Society, Elsevier, available at: www.sciencedirect.com/science/ article/abs/pii/S2210670720305710.

Mehta, V. (2020), The New Proxemics: COVID-19, Social Distancing, and Sociable Space, Taylor \& Francis, available at: https://www.tandfonline.com/doi/full/10.1080/13574809.2020.1785283.

Muhammad, F. (2020), "COVID-19 pandemic: a global economic challenge”, Hormozgan Medical Journal, e104280.

Rahman, M.S., Azad, M.A.K., Hasanuzzaman, M., Salam, R., Islam, A.R.M.T., Rahman, M.M. and Hoque, M.M.M. (2020), "How air quality and COVID-19 transmission change under different lockdown scenarios? A case from Dhaka city, Bangladesh”, Science of The Total Environment, p. 143161.

Rashid, H., Afonso, H., Pitterle, I. and Vergata, S. (2020), "Commodity exporters face mounting economic challenges as Covid-19 pandemic spreads", Policy Brief No. 60, pp. 1-4, April 2020.

\section{Impact of} Covid-19 on built environment 
FEBE

2,2

80

Sadik-Kahn, J. and Solomonow, S. (2017), Streetfight: Handbook for an Urban Revolution, Penguin, New York, NY.

Sallis, J.F., Adlakha, D., Oyeyemi, A. and Salvo, D. (2020), "An international physical activity and public health research agenda to inform coronavirus disease-2019 policies and practices", Journal of Sport and Health Science, Vol. 9, pp. 328-34, doi: 10.1016/j.jshs.2020.05.005.

Sharma, S. and Jeevan, B. (2021), "Public health challenges during the COVID-19 outbreak in Nepal: a commentary", COVID, available at: https://covid19.elsevierpure.com/en/publications/publichealth-challenges-during-the-covid-19-outbreak-in-nepal-a.

Vasantha Raju, N. and Patil, S.B. (2020), "Indian publications on SARS-CoV-2: a bibliometric study of WHO Covid-19 database", Diabetes and Metabolic Syndrome: Clinical Research and Reviews, Elsevier, available at: www.sciencedirect.com/science/article/abs/pii/S1871402120302538.

Velarde, M.D., Fry, G. and Tveit, M. (2007), "Health effects of viewing landscapes - Landscape types in environmental psychology", Urban Forestry and Urban Greening, Vol. 6, pp. 199-212, doi: 10. 1016/j.ufug.2007.07.001.

Zhang, H. and Rajib, S. (2020), "Identifying research trends and gaps in the context of Covid-19", International Journal of Environmental Research and Public Health, Vol. 17 No. 10, p. 3370, doi: 10.3390/ijerph17103370.

\section{Corresponding author}

M. Mahima can be contacted at: mm2181@srmist.edu.in

For instructions on how to order reprints of this article, please visit our website:

www.emeraldgrouppublishing.com/licensing/reprints.htm

Or contact us for further details: permissions@emeraldinsight.com 